\title{
Early generation in vitro assay to identify potato populations and clones tolerant to heat
}

\author{
M. Awais Khan $\cdot$ Susan Munive $\cdot$ Merideth Bonierbale
}

Received: 31 August 2014/ Accepted: 28 November 2014/Published online: 9 December 2014

(C) The Author(s) 2014. This article is published with open access at Springerlink.com

\begin{abstract}
An efficient in vitro system for early generation selection of heat-tolerant potato breeding materials was tested and validated in field conditions. At the family level, family groups expected to be heat tolerant due to their genetic background were identified as heat tolerant. In the in vitro assay, LTVR $\times$ LTVR, an advanced heat-tolerant breeding population developed at CIP, had $100 \%$ of plants with tubers at $18{ }^{\circ} \mathrm{C}, 73 \%$ at $25{ }^{\circ} \mathrm{C}$ and $2 \%$ at $32{ }^{\circ} \mathrm{C}$ in the dark. The results from true seed family level in vitro screening at $25^{\circ} \mathrm{C}$ and tuber family evaluation under field conditions in Tacna, an arid sub-tropical environment in Southern Peru, were positively correlated $(r=0.57)$. There was low to moderate correlation between percentage of plants with tubers under $27^{\circ} \mathrm{C}$ in vitro temperature treatment and harvest index in the in vivo conditions in Majes-Arequipa, San Ramon, and La Molina that followed increasing temperature ranges between the sites. This indicates that the methodology can predict putative heat tolerant clones with a low level of confidence. Low correlation is possibly due to differential responses of the clones to characteristics of the growing environment, such as soil versus media, which were not represented in the in vitro assay, as well as the fact that in the field, day-night temperatures vary during tuberization and tuber filling, and throughout the season, while in vitro temperature and the dark period were kept constant, and conditions were
\end{abstract}

Electronic supplementary material The online version of this article (doi:10.1007/s11240-014-0677-z) contains supplementary material, which is available to authorized users.

M. A. Khan $(\bowtie) \cdot$ S. Munive $\cdot$ M. Bonierbale

International Potato Center (CIP), Av. La Molina 1895,

Apartado 1558, Lima 12, Peru

e-mail: awais.khan@cgiar.org controlled specifically to assess tuberization (tuber induction) at high night temperatures. The ability of the in vitro seedling screening assay to identify families tolerant to high temperatures in an inexpensive and less time consuming way without need of transplanting experimental material to the field will facilitate evaluation of significant samples of genetic resources and improved populations in breeding programs attempting to improve potato for adaptation to new environments and climate change.

Keywords Heat tolerance $\cdot$ In vitro $\cdot$ In vivo $\cdot$ Potato Screening assay $\cdot$ Tuberization

\section{Introduction}

Climate change is widely recognized as one of the major issues facing the globe, with potential temperature increases across the world of up to $6.2{ }^{\circ} \mathrm{C}$ by the year 2100 (Peters et al. 2013). Environmental stresses (heat, drought, waterlogging, salinity, and elevated $\mathrm{CO}_{2}$ ) have become more frequent, aggravated by the rapid climate change of recent decades (Chapman et al. 2012). Meanwhile, the world's food situation is being redefined by new driving forces affecting consumption, production, and markets (Von Braun 2007). Abiotic stress and the rapid increase in potato production and consumption needs pose a great challenge to sustained growth in world potato production and the assurance of high quality produce needed for local and global trade (Hijmans 2003; Pandey 2008).

Potato is an annual herbaceous crop plant, vegetatively propagated via tubers. Growth of a potato plant occurs in several stages: sprout development, plant establishment, tuber initiation, tuber bulking, and tuber maturation. Timing of these growth stages varies depending upon genetic 
make-up as well as environmental factors such as temperature, photoperiod, soil type, availability of moisture, and storage conditions of tuber seed (Griffin et al. 1993).

Temperature plays a key role in regulating growth and yield in potatoes (Bodlaender 1963; Tibbitts et al. 1989). The potato tuber is an enlarged portion of the stolon and its initiation is triggered by short day lengths (photoperiods). Tuberization in potato is a highly complex developmental process, which may be affected in various ways, for example, growth at $17{ }^{\circ} \mathrm{C}$ maximizes tuberization (Gregory 1965), whereas growth at $25^{\circ} \mathrm{C}$ maximizes top growth (Benoit et al. 1983). The optimum soil temperature for tuber initiation is $15-20{ }^{\circ} \mathrm{C}$, and the colder the soil temperature, the more rapid the initiation of tubers and the greater the number of tubers formed. Also, a day/night temperature fluctuation (thermoperiod) is considered necessary for maximum tuber yields (Benoit et al. 1986; Ewing 1981). A high day and low night temperature cycle of $22 / 14{ }^{\circ} \mathrm{C}$ with a 12 -h photoperiod promoted growth and tuberization in potatoes as compared to a constant $18{ }^{\circ} \mathrm{C}$, although the amount of promotion from temperature fluctuation varies across genotypes (Bennett et al. 1991).

Optimum soil and air temperatures lead to a good balance between vine and tuber growth (Griffin et al. 1993). Potatoes need moderate amounts of nitrogen and cool nights for good tuber growth. High soil temperatures, in particular, will result in an imbalance in source-sink relation and delay tuber initiation and filling (Midmore 1992; Midmore and Prange 1992; Midmore and Roca 1992). Physiological disorders including malformation of tubers, chain tubers, heat sprouting, and internal heat necrosis resulting in an unacceptable browning of the tuber tissue are among the negative consequences of exposure of potato genotypes to heat stress. These disorders are mainly caused by elevated soil temperatures during the latter stages of tuber growth and development, and can cause economic losses to the grower (Stevenson et al. 2001; Struik and Ewing 1995). Malformation of tubers under heat stress is primarily due to decreased cell division and irregular supply of carbohydrates available to the tuber (Krauss and Marschner 1984; Lafta and Lorenzen 1995; Wolf et al. 1991).

The principal goal for growers is usually to produce the highest yield possible, but quality is equally important. The marketability of fresh or processing potatoes is dependent on the production of tubers with consistently high quality, measured as tuber shape, external appearance, specific gravity, the lack of internal and external defects, disease, or pest damage (Hiller and Thornton 1993). Breeding requires the assessment of genetic diversity for adaptation and quality traits, and the selection and recombining of genetic resources into new varieties (Levy and Veilleux 2007). Methodologies yielding reliable information on crop performance in short timeframes can significantly enhance selection processes and speed up breeding efforts to meet changing production needs (Anderson and Howard 1981; Brown et al. 1987; Gopal et al. 1994).

Although research has been carried out on microtuber production in potato, little attention has been given to in vitro tuberization screening for heat tolerance as a selection strategy for breeding of heat tolerant potatoes. Efficient methodologies are needed for quick identification of source genotypes with high potential to face the dual challenges of environmental adaptation and higher productivity (Levy et al. 1991; Russo and Slack 1998). Here we present development, validation and improvement of a method for identifying heat-tolerant potato breeding materials in the early stages of a breeding and clonal selection program.

\section{Materials and methods}

The family level in vitro assay for heat tolerance screening was developed using true seed families and validated using tuber families grown in field conditions. A second experiment compared in vitro tuberization of clonal stocks (clonal level assay) with their in vivo tuberization in pots in three field locations.

In vitro heat tolerance assay at family level

Random samples of heterogeneous potato families with different genetic backgrounds and different expected tuberization capacity under high temperatures were taken from crosses within and between two advanced populations of the International Potato Center's (CIP) breeding program, and Solanum tuberosum varieties. Two advanced populations: Lowland tropics virus resistant (LTVR) population characterized by virus resistance, heat tolerance, sub-tropical lowland adaptation and earliness; and B3 population characterized by late blight resistance and cool, highland adaptation, and Solanum tuberosum varieties adapted to long day conditions, called TBR in this study, were sampled. Twenty bi-parental, intra- and inter-population families were classified into five groups according to their cross combination set (Table 1).

\section{In vitro assay}

The in vitro family level assay was established in the in vitro laboratory at CIP using three replications of 20 seeds of each of 20 true seed families per treatment. First, seed dormancy was broken by treatment with 1,500-ppm gibberelic acid for $24 \mathrm{~h}$ before seed disinfection. The family level in vitro assay employed three temperature treatments: 18,25 , and $32{ }^{\circ} \mathrm{C}$. True seed (TS) was 
Table 1 List of controlled-cross potato families used for in vitro heat tolerance family level assay

\begin{tabular}{|c|c|c|c|c|}
\hline ID & Source Population & Family (Cross code) & Female Parent & Male Parent \\
\hline 1 & $\mathrm{~B} 3 \times \mathrm{B} 3$ & CIP 302513 & CIP 391002.6 & CIP 396272.18 \\
\hline 2 & $\mathrm{~B} 3 \times \mathrm{B} 3$ & CIP 302533 & CIP 393371.159 & CIP 396272.43 \\
\hline 3 & $\mathrm{~B} 3 \times \mathrm{B} 3$ & CIP 303082 & CIP 391004.18 & CIP 393074.86 \\
\hline 4 & $\mathrm{~B} 3 \times \mathrm{B} 3$ & CIP 398017 & CIP 391002.6 & CIP 392639.31 \\
\hline 5 & $\mathrm{~B} 3 \times \mathrm{B} 3$ & CIP 398183 & CIP 392657.8 & CIP 392633.54 \\
\hline 6 & $\mathrm{~B} 3 \times \mathrm{TBR}$ & CIP 304019 & CIP 391004.18 & Pirola \\
\hline 7 & $\mathrm{~B} 3 \times \mathrm{TBR}$ & CIP 304107 & CIP 393242.5 & Desiree \\
\hline 8 & $\mathrm{LTVR} \times \mathrm{LTVR}$ & CIP 302496 & CIP 392797.22 & CIP 392820.1 \\
\hline 9 & $\mathrm{LTVR} \times \mathrm{LTVR}$ & CIP 303407 & CIP 388615.22 & CIP 391180.6 \\
\hline 10 & $\mathrm{LTVR} \times \mathrm{LTVR}$ & CIP 303408 & CIP 388615.22 & CIP 392820.1 \\
\hline 11 & LTVR-B3 & CIP 303088 & CIP 391065.81 & CIP 392745.7 \\
\hline 12 & LTVR-B3 & CIP 303098 & CIP 391065.81 & CIP 392820.1 \\
\hline 13 & LTVR-B3 & CIP 303139 & CIP 392650.49 & CIP 392745.7 \\
\hline 14 & LTVR-B3 & CIP 303183 & CIP 393227.66 & CIP 392820.1 \\
\hline 15 & LTVR-B3 & CIP 303405 & CIP 388615.22 & CIP 393280.64 \\
\hline 16 & LTVR-B3 & CIP 303609 & CIP 391562.6 & CIP 393074.86 \\
\hline 17 & $\mathrm{TBR} \times \mathrm{LTVR}$ & CIP 302328 & Desiree & CIP 392745.7 \\
\hline 18 & $\mathrm{TBR} \times \mathrm{LTVR}$ & CIP 302330 & Desiree & CIP 391180.6 \\
\hline 19 & $\mathrm{TBR} \times \mathrm{LTVR}$ & CIP 302476 & Titia & CIP 392745.7 \\
\hline 20 & $\mathrm{TBR} \times \mathrm{LTVR}$ & CIP 302478 & Titia & CIP 392820.1 \\
\hline
\end{tabular}

Families are from crosses within and between two advanced breeding populations of the International Potato Center (CIP) and Solanum tuberosum varieties, classified into five groups according to their cross combination set. LTVR, B3, and TBR are Lowland Tropics Virus Resistant population, late blight resistant population, and $S$. tuberosum varieties, respectively

disinfected twice, once outside a flow chamber and once inside the flow chamber. Outside of the flow chamber, TS was soaked for $15 \mathrm{~min}$ in a solution of $2 \mathrm{mg}^{-1}$ Farmathe $^{\circledR}$ $50 \mathrm{PM}$ (fungicide), $1 \mathrm{mg}^{-1}$ of Nissorum ${ }^{\circledR}$ (acaricide), $1 \mathrm{ml} \mathrm{l}^{-1}$ Peropal $^{\circledR}$ (miticide), and 3 drops of Tween-20 ${ }^{\circledR}$ non-ion detergent and rinsed with distilled water. Inside the flow chamber, TS was soaked for $30 \mathrm{~s}$ in alcohol, then 10 min in $3.5 \% \mathrm{NaCl}$ solution, and finally rinsed with sterile water. TS was germinated under constant shaking in $250 \mathrm{ml}$ flasks in $30 \mathrm{ml}$ liquid-growing medium consisting of Murashige and Skoog (1962) medium (MS) supplemented with $1.5 \mathrm{mg} \mathrm{l}^{-1}$ kinetine, $0.05 \mathrm{mg} \mathrm{l}^{-1}$ gibberellic acid, and $3 \%$ sucrose, under a $16 \mathrm{~h}$ photoperiod of 3,000-4,000 lux light intensity at $18 \pm 2{ }^{\circ} \mathrm{C}$ day/night temperatures. After 5 weeks, the growing medium was replaced by tuberization medium and the plants were subjected to constant dark at three different temperatures $\left(18,25\right.$, or $\left.32{ }^{\circ} \mathrm{C}\right)$ for 5 weeks. Tuberization medium consisted of MS medium supplemented with $8 \%$ sucrose, 5 - $\mathrm{mg}^{-1}$ benzyl amino purine, and $500 \mathrm{mg}^{-1}$ cycocel. The percentage of seedlings per family with tubers (percent of genotypes with tubers, PGT) was determined by counting the tubers visible in the flask at the end of the tuberization stage (10-12 weeks).

\section{Field validation}

The family level in vitro assay was validated in a field experiment. The field experiment was conducted under a Randomized Complete Block Design (RCBD) at Tacna (439 masl), in the South of Peru in the summer of 2008. Seedling tubers of twenty families (tuber families) produced under greenhouse conditions were established in the field with three replications of 30 genotypes each. During the growing season, night temperatures ranged from 10 to $21^{\circ} \mathrm{C}$, whereas day temperature ranged from 26 to $32^{\circ} \mathrm{C}$. Trait data recorded in the field were percentage of genotypes per family with tubers (PGT).

In vitro heat tolerance assay at clonal level

In vitro plantlets of a set of 20 clones comprising varieties and clones from CIP's Lowland Tropics Virus Resistant population (LTVR) and late blight resistant population (B3), with variable tolerance to high temperature were used to test the suitability of in vitro conditions to identify heat tolerant clones, and results validated in in vivo conditions in three field sites, as a complement to the family level assay (Table 2). 
Table 2 List of potato clones used for in vitro heat tolerance clonal level assay

\begin{tabular}{llll}
\hline $\mathrm{Nr}$ & $\begin{array}{l}\text { Source } \\
\text { Population }\end{array}$ & $\begin{array}{l}\text { Clone (Selection } \\
\text { code) }\end{array}$ & $\begin{array}{l}\text { Breeders' code/Cultivar } \\
\text { Name }\end{array}$ \\
\hline 1 & B3 & CIP 393371.157 & - \\
2 & B3 & CIP 393077.159 & - \\
3 & B3 & CIP 392633.54 & - \\
4 & B3 & CIP 391002.6 & - \\
5 & B3 & CIP 396244.17 & - \\
6 & B3 & CIP 396004.263 & - \\
7 & B3 & CIP 395037.107 & - \\
8 & LTVR & CIP 377258.1 & LT-2 \\
9 & LTVR & CIP 397036.7 & - \\
10 & LTVR & CIP 397077.16 & - \\
11 & LTVR & CIP 395434.1 & - \\
12 & LTVR & CIP 395192.1 & - \\
13 & LTVR & CIP 388615.22 & C91.640 \\
14 & TBR & CIP 800938 & AVRDC-1287.19 \\
15 & TBR & CIP 800048 & Desiree \\
16 & B3 & CIP 720072 & Tomasa Condemayta \\
17 & B3 & CIP 380389.1 & Canchan-INIA \\
18 & LTVR & CIP 390478.9 & Tacna \\
19 & LTVR & CIP 388676.1 & Maria Bonita-INIA \\
20 & LTVR & CIP 388611.22 & Reiche \\
\hline
\end{tabular}

Clones are from two advanced breeding populations, Lowland tropics virus resistant (LTVR) and late blight resistant (B3) populations of the International Potato Center (CIP) while TBR are Solanum tuberosum varieties

\section{In vitro assay}

Plants used for the clonal level assay were taken from in vitro storage, and each of 4 nodal cuttings were transferred to propagation medium to provide sufficient material. Twenty nodal cuttings from each clone were transferred to $250 \mathrm{ml}$ flasks under constant shaking in $30 \mathrm{ml}$ liquid growing medium consisting of MS (Murashige and Skoog 1962) medium supplemented with $1.5 \mathrm{mg}^{-1}$ kinetine, $0.05 \mathrm{mg} \mathrm{l}^{-1}$ gibberellic acid, and $3 \%$ sucrose under a $16 \mathrm{~h}$ photoperiod of 3,000-4,000 lux light intensity at $18 \pm 2{ }^{\circ} \mathrm{C}$ constant temperature. After 5 weeks, the growing medium was replaced by tuberization medium and the plants were subjected to constant dark at three temperatures $\left(18,27\right.$, or $\left.30^{\circ} \mathrm{C}\right)$ for 5 weeks. Tuberization medium consisted of MS medium supplemented with $8 \%$ sucrose, $5 \mathrm{mg} \mathrm{l}^{-1}$ benzyl amino purine, and $500 \mathrm{mg} \mathrm{l}^{-1}$ cycocel. Percentage of plants with tubers (PPT), and fresh weight of microtubers (mg, MtFW) were recorded.

\section{In vivo validation}

The same set of 20 clones and three controls from the in vitro clonal experiments was used to assess behavior under in vivo conditions with heat stress (Table 2) Three experiments were carried out in the contrasting environments of: La Molina-Lima; a heat stress site (lowland 200 msal), Majes-Arequipa (lowland 600 masl); a low heat stress site, and San Ramon (jungle 1,800 msal), a heat stress site. Experiments were conducted between January and May 2012 (summer season) in a completely randomized design (CRD) with 23 genotypes and 10 replications. For in vivo validation, plantlets were obtained from in vitro and planted in Jiffy pots for growing up to $50 \mathrm{~cm}$, then transplanted to 10 inch pots and placed under field conditions. The same soil was used in the three experiments to minimize soil environment effects or interaction with genetic and temperature effects. Data was recorded for percentage of plants tuberized (PPT) fresh weight of tubers by pot (g/pot, TFW), dry weight of tubers by pot (g/pot, TDW), dry weights of leaf, stem and roots were taken and used to calculate total biomass on dry weight basis, and harvest index $(\mathrm{HI})$, and dry matter content $(\mathrm{DM}=\mathrm{TDW} /$ TFW $\times 100)$.

Statistical analysis

Outlier detection, distribution of data, difference between families and clones for in vitro as well as field and in vivo experiments were performed using Minitab 14 (Minitab Inc., State College, PA, USA). Additional statistical analysis to identify differences between in vitro heat tolerance assay at family level and clonal level was done using SAS Version 9.2 and STAT software (SAS Institute, Cary, NC) by using transformed PGT and PPT data. In SAS program, proc glm and PROC MIXED statements were used to obtain least square mean (LSmeans) values. Further, LSmeans obtained from crossing groups and families were also used for spearman correlation analysis.

\section{Results and discussion}

An efficient in vitro assay for early generation selection of heat tolerant potato progenies and clones was established and validated in field conditions. True seed-derived families showed good performance on MS liquid growing medium, with all material in the same condition before being transferred to tuberization medium and exposed to temperature treatments. All families had genotypes that produced microtubers at 18 and $25{ }^{\circ} \mathrm{C}$, with tuberization rates depending on crossing group and family. Tuberization rates of families ranged from $52.6 \pm 24.3$ to $56.8 \pm 22.6 \%$ in the $18{ }^{\circ} \mathrm{C}$ treatment to and from $25.1 \pm 22$ to $55.2 \pm 15.8 \%$ in the $25{ }^{\circ} \mathrm{C}$ treatment (Fig. 1; Supplementary Table 1). The microtuber production in the $32{ }^{\circ} \mathrm{C}$ temperature treatment was very low and 
Fig. 1 Percentage of genotypes with tubers (PGT) of tuber families from $\mathrm{B} 3 \times \mathrm{B} 3$,

B3 $\times$ LTVR, LTVR $\times$ B3, LTVR $\times$ LTVR and

TBR $\times$ LTVR crossing groups in the family level assay under in vitro at $18,25^{\circ} \mathrm{C}$, and field conditions in Tacna during summer 2008. LTVR, B3, and TBR are Lowland tropics virus resistant and, late blight resistant populations of the International Potato Center (CIP), and Solanum tuberosum varieties, respectively

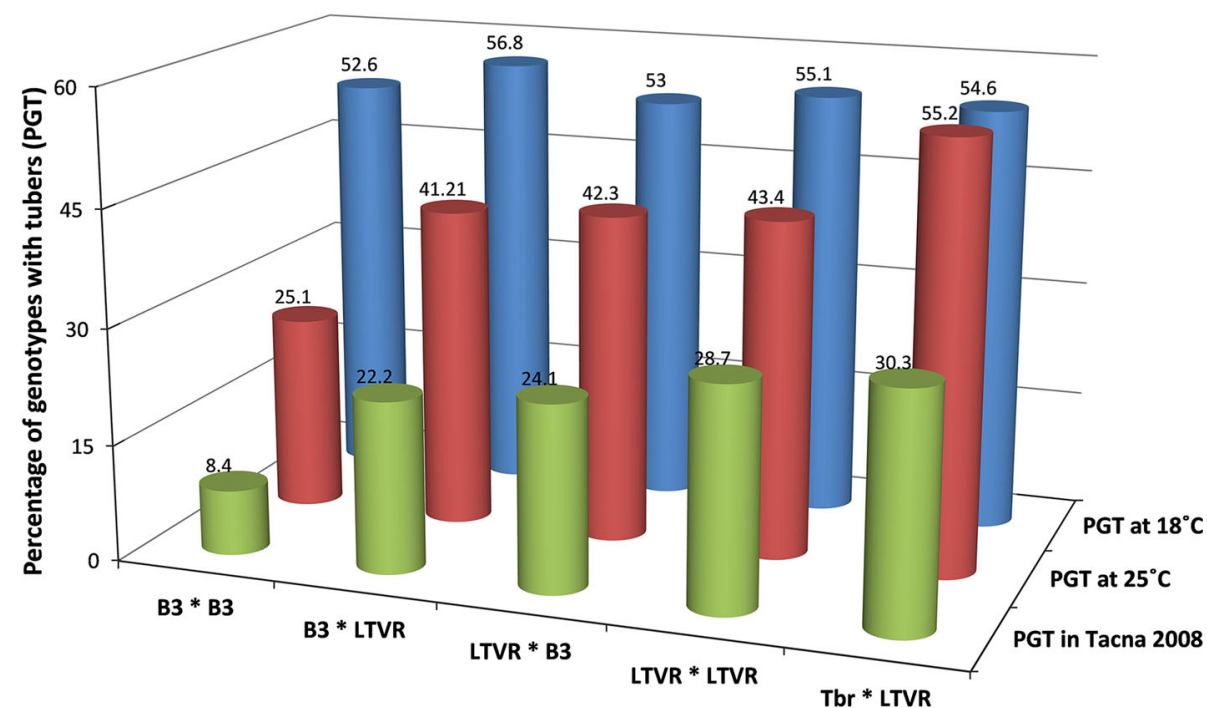

B

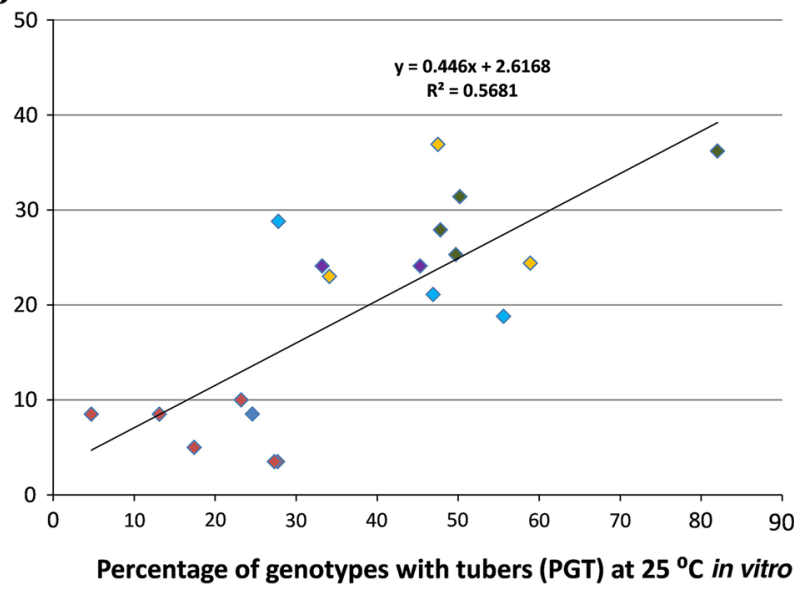

LTVR $\times$ B3, LTVR $\times$ LTVR, and TBR $\times$ LTVR groups, respectively. LTVR, B3, and TBR are Lowland tropics virus resistant and, late blight resistant populations of the International Potato Center (CIP), and Solanum tuberosum varieties, respectively. (Color figure online)

B3 $\times$ B3 (Fig. 1; Supplementary Table 1). Some exceptions to expected performance of families within crossing groups based on their population origin suggested that the in vitro assay may detect heritable variation for heat tolerance within, as well as between, populations. For example, four LTVR families had less than $40 \%$ tuberization (PGT) and two B3 families had over $60 \%$ tuberization (PGT) (Supplementary Table 1).

Correlation between PGT in the family level assay for the $25^{\circ} \mathrm{C}$ temperature treatment in vitro and in vivo stress condition is positive and significant $(r=0.57)$, while the correlation between PGT at $18{ }^{\circ} \mathrm{C}$ and in vivo conditions was not significant $(r=0.0008)$ (Fig. 2). The temperatures in the field site in Tacna ranged from 10 to $21^{\circ} \mathrm{C}$ (night while the lowest tuberization rates were found for 
temperature) and 26 to $32{ }^{\circ} \mathrm{C}$ (day temperature), during the growing season in summer 2008. There is no direct correlation between the $18{ }^{\circ} \mathrm{C}$ PGT and the field in Tacna for several reasons. The field experiment experiences a varying environment, with fluctuations in temperature between day and night, light conditions, and soil type, while the in vitro experiment has constant temperature, photoperiod, and light quality and quantity for each developmental stage. Besides the fluctuations mentioned, the high temperatures during the day in Tacna reached up to $32{ }^{\circ} \mathrm{C}$ day temperatures and this may have influenced vigor and phenology. The overall low rates of tuberization in the $32{ }^{\circ} \mathrm{C}$ in vitro (dark period) treatment with respect to the field experiment which allowed tuber production even though highs of $32{ }^{\circ} \mathrm{C}$ were reached in the day time, attests to the specificity of the in vitro assay, which was designed to assess the sensitivity of potato populations to heat as a factor of their tuberization response (tuber induction at specified night temperatures).

Families that were highly ranked in both the in vitro assay at $25{ }^{\circ} \mathrm{C}$ and validation in field conditions in Tacna were either from the cross between TBR $\times$ LTVR or LTVR $\times$ LTVR (Supplementary Table 1 ). The best family at $25^{\circ} \mathrm{C}$ was 302478 from TBR $\times$ LTVR, with $82 \pm 11.4 \%$ tuberization (PGT). This family was also the second best in the in vivo conditions in Tacna, where it had $36.2 \pm 3.3$ PGT. Under field conditions in Tacna, family CIP 303408 (LTVR $\times$ LTVR) had the highest percentage of genotypes with tuberization $(36.9 \pm 11.2 \%)$ and had $47.5 \pm 26.2 \%$ PGT at $25{ }^{\circ} \mathrm{C}$ in the in vitro assay, ranking 7 th.

The clonal level in vitro heat tolerance assay and its validation in vivo showed moderate ability of the in vitro technique to identify genotypes with adaptation to heat (Fig. 3). Although overall correlation between performance under in vitro and in vivo field conditions is not strong, clones identified as heat-tolerant were predominantly from LTVR population. The assay shows a decrease in tuberization performance of clones with increasing temperature, with heat tolerance generally as expected from the information according to pedigree and breeders' knowledge of population performance. Patterns of correlation in the clonal level assay between the percentage of plants with tubers (PPT) at $27^{\circ} \mathrm{C}$ in vitro and $\mathrm{HI}$ data collected from in vivo field sites (Fig. 3) follow the temperature differences between the sites: La Molina-Lima $\left(21-35^{\circ} \mathrm{C}\right)$, Majes-Arequipa $\left(15-24{ }^{\circ} \mathrm{C}\right)$, and San Ramon $\left(20-26^{\circ} \mathrm{C}\right)$. The range of $\mathrm{HI}$ in in vivo experiments at the three locations used for validation of the clonal level assay was variable, which could be attributed to the differences in the environment partly reflected by minimum and maximum temperatures during the growing season. $\mathrm{HI}$ of the clones under in vivo heat stress conditions of La Molina and San
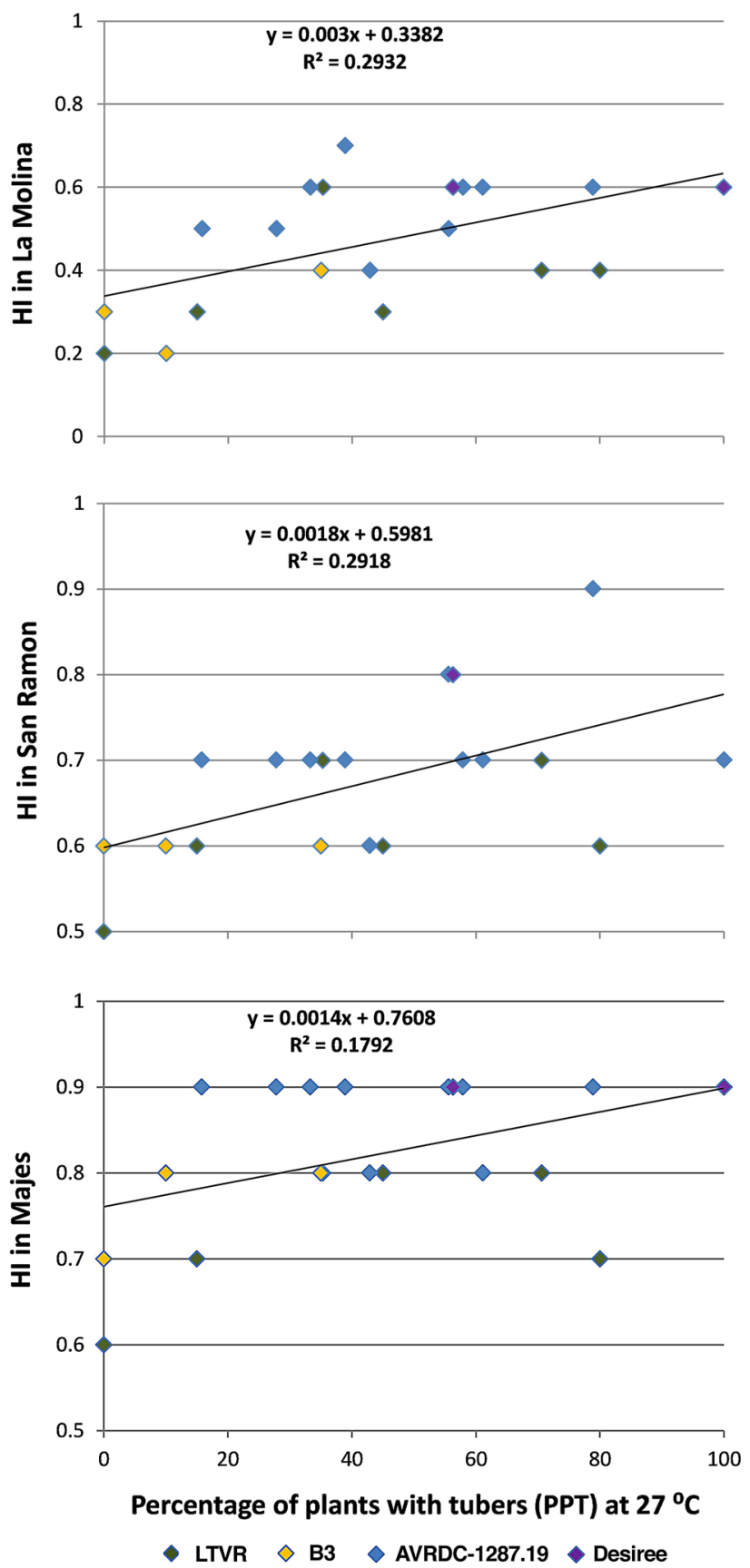

Fig. 3 Correlation between percentage of plants with tubers (PPT) at $27{ }^{\circ} \mathrm{C}$ in vitro in the clonal level assay and harvest index (HI) at three in vivo validation field sites (La Molina, Majes, and San Ramon) green, yellow, blue, and purple dots are clones from Lowland tropics virus resistant (LTVR), late blight resistant (B3) clones from CIP's advanced breeding populations, and two clones considered to be heat tolerant (AVRDC-1287.19 and Desiree), respectively. (Color figure online)

Ramon was moderately correlated $(r=0.29)$ to PPT under heat stress conditions at $27{ }^{\circ} \mathrm{C}$ treatment of the in vitro assay (Fig. 3). This low to moderate correlation between PPT under $27^{\circ} \mathrm{C}$ in vitro temperature treatment and $\mathrm{HI}$ in the La Molina and San Ramon summer experiments indicates that the methodology can predict putative heat 
tolerant clones with a low level of confidence. This low correlation is possibly due to differential responses of the clones to characteristics of the growing environment, such as soil versus media, which were not represented in the in vitro assay, as well as the fact that in the field, day-night temperatures vary during tuberization and tuber filling, and throughout the season, while in vitro temperature and the dark period were kept constant. Temperature and environment had great influence over potato clone tuberization, and high temperature significantly reduces potato production. According to Bennett et al. (1991), fluctuation in environmental temperature between 14 and $22{ }^{\circ} \mathrm{C}$ is good for tuber induction.

Additionally, the stable variety 'Desiree' showed similar performance under three temperature treatments in vivo and in vitro, and a promising heat tolerant clone, CIP 397077.16, from CIP's LTVR population showed a similar heat tolerance tendency under the $27{ }^{\circ} \mathrm{C}$ treatment. The performance of potato clones Desiree, LT2, Avrdc-128719, Reiche, and Tacna in La Molina in vivo environment was similar to their performance under in vitro screening method, demonstrating that the in vitro screening method could be a tool capable of selecting potato clones with heat tolerance and discarding susceptible clones. Varieties such as Tomasa Condemayta, and 396244.17 are good candidates for heat tolerance. These results are consistent with previous reports where Nowak and Colborne (1989) confirmed CIP breeding line LT2 as a heat resistant clone, Midmore and Prange (1991) noted that AVRDC 1287.19 produced more dry weight in the hot chamber than the cool chamber, and Carli et al. (2009) confirmed Reiche, Tacna, and CIP 397077.16 as well-adapted clones for hot summer conditions of Central Asia.

Both family and clonal level assays identified crossing groups of families according to their expected tuberization capacity under heat stress, which correlated low to moderately well with their performance in the field and in vivo evaluations for heat tolerance. Families and clones responded to heat stress according to their population origin, with some exceptions that are not surprising considering the genetic base of each source population. Also, there is a slight variation in temperature treatments of clonal assay compared to family level assay, where 18, 27, and $30{ }^{\circ} \mathrm{C}$ were used, according to experiments related to heat tolerance (Das et al. 2000; Havaux 1993, 1992). This slight difference is not expected to be the main reason for the differences between clonal and family level in vitro assays. In summary, in vitro screening can help discriminate heat-tolerant groups of potato germplasm and may have practical implications for use in potato breeding programs seeking to identify heat-tolerant families or genotypes. In a population improvement program, for example, the in vitro family assay can be used to reflect parental value and identify the most tolerant families to be advanced in a selection program. The in vitro assay at the clonal level can be used to assess clonal collections for sources of heat tolerance.

Acknowledgments Authors acknowledge the financial support by Rural Development Administration (RDA) of the Republic of Korea through a research grant for "Breeding of potato cultivars tolerant to high temperature and adapted to long days with improved quality traits for variety selection in East Asia against global climate change". We thank Eng. Walter Amoros for his help in evaluations during the experiment, and Dr. Hyun-Jun Kim and Dr. Young-Eun Park for design, installation, evaluation, and interpretation of the experiment.

Open Access This article is distributed under the terms of the Creative Commons Attribution License which permits any use, distribution, and reproduction in any medium, provided the original author(s) and the source are credited.

\section{References}

Anderson JAD, Howard HW (1981) Effectiveness of selection in the early stages of potato breeding programmes. Potato Res 24:289-299

Bennett SM, Tibbitts TW, Cao W (1991) Diurnal temperature fluctuation effects on potatoes grown with $12 \mathrm{hr}$ photoperiods. Am Potato J 68:81-86

Benoit GR, Stanley CD, Grant WJ, Torrey DB (1983) Potato top growth as influenced by temperatures. Am Potato J 60:489-501

Benoit GR, Grant WJ, Devine OJ (1986) Potato top growth as influenced by day-night temperature differences. Agron J 78:264-269

Bodlaender KBA (1963) Influence of temperature, radiation and photoperiod on development and yield. In: Ivins JD, Milthorpe FL (eds) The growth of the Potato. Butterworth, London, p 199

Brown J, Caligari PDS, Mackay GR, Swan GEL (1987) The efficiency of visual selection in early generations of a potato breeding programme. Ann Appl Biol 110:357-363

Carli C, Bonierbale M, Amoros W, Yuldashev F, Khalikov D, Abdurakhmanov T, Rasulov AI (2009) Adaptability and storability of CIP potato clones under long-day conditions of central Asia. Paper presented at the 15 th Triennial ISTRC Symposium, Lima, Peru

Chapman SC, Chakraborty S, Dreccer MF, Howden SM (2012) Plant adaptation to climate change-opportunities and priorities in breeding. Crop Pasture Sci 63:251-268

Das A, Gosal SS, Sidhu JS, Dhaliwal HS (2000) Induction of mutations for heat tolerance in potato by using in vitro culture and radiation. Euphytica 114:205-209

Ewing EE (1981) Heat stress and the tuberization stimulus. Am Potato J 58:31-49

Gopal J, Gaur PC, Rana MS (1994) Heritability, and intra- and intergeneration associations between tuber yield and its components in potato (Solanum tuberosum L.). Plant Breed 112:80-83

Gregory LE (1965) Physiology of tuberization in plants (tubers and tuberous roots). In: Lang A (ed) Differenzierung Und Entwicklung/Differentiation and Development, Handbuch der Pflanzenphysiologie/Encyclopedia of Plant Physiology 15 (1). Springer, Berlin Heidelberg, pp 1328-1354

Griffin TS, Johnson BS, Ritchie JT (1993) IBSNAT Research report series 02. A Simulation model for potato growth and 
development: SUBSTOR-Potato version 2.0. Dept. of Agronomy and Soil Science, College of Tropical Agriculture and Human Resources, Univ. of Hawaii, Honolulu, HI

Havaux M (1992) Stress tolerance of photosystem II in vivo antagonistic effects of water, heat, and photoinhibition stresses. Plant Physiol 100:424-432

Havaux M (1993) Rapid photosynthetic adaptation to heat stress triggered in potato leaves by moderately elevated temperatures. Plant Cell Env 16:461-467

Hijmans RJ (2003) The effect of climate change on global potato production. Am J Potato Res 80:271-279

Hiller LK, Thornton RE (1993) Management of physiological disorders. In: Rowe RC (ed) Potato health management. APS Press, St. Paul, pp 87-94

Krauss A, Marschner H (1984) Growth rate and carbohydrate metabolism of potato tubers exposed to high temperatures. Potato Res 27:297-303

Lafta AM, Lorenzen JH (1995) Effect of high temperature on plant growth and carbohydrate metabolism in potato. Plant Physiol 109:637-643

Levy D, Veilleux RE (2007) Adaptation of potato to high temperatures and salinity-a review. Am J Potato Res 84:487-506

Levy D, Kastenbaum E, Itzhak Y (1991) Evaluation of parents and selection for heat tolerance in the early generations of a potato (Solanum tuberosum L.) breeding program. Theor Appl Genet 82:130-136

Midmore DJ (1992) Potato production in the tropics. In: Harris P (ed) The Potato crop: the scientific basis for improvement, 2nd edn. Chapman and Hall, London, pp 728-793

Midmore DJ, Prange RK (1991) Sources of heat tolerance amongst potato cultivars, breeding lines, and Solanum species. Euphytica 55:235-245

Midmore DJ, Prange RK (1992) Growth responses of two Solanum species to contrasting temperatures and irradiance levels: relations to photosynthesis, dark respiration and chlorophyll fluorescence. Ann Bot 69(1):13-20
Midmore DJ, Roca J (1992) Influence of production and storage conditions on subsequent growth and tuber yield of potato (Solanum spp.) in the hot tropics. J Agr Sci 119(01):45-58

Murashige T, Skoog F (1962) A revised medium for rapid growth and bio assays with tobacco tissue cultures. Physiol Plant $15: 473-497$

Nowak J, Colborne D (1989) In vitro tuberization and tuber proteins as indicators of heat stress tolerance in potato. Am Potato $\mathrm{J}$ $66: 35-45$

Pandey SK (2008) Potato research priorities in Asia and the Pacific region. Paper presented at workshop to commemorate the international year of the Potato. Bangkok, Thailand. RAP Publ. FAO

Peters GP, Andrew RM, Boden T, Canadell JG, Ciais P, Le Quéré C, Marland G, Raupach MR, Wilson C (2013) The challenge to keep global warming below 2 C. Nat Clim Change 3:4-6

Russo P, Slack SA (1998) Tissue culture methods for the screening and analysis of putative virus-resistant transgenic potato plants. Phytopathology 88:437-441

Stevenson WR, Loria R, Franc GD, Wein-gartner DP (2001) Physiological disorders of tubers: internal Symptoms. In: Compendium of Potato Diseases (2nd ed.), APS Press, St. Paul, $\mathrm{MN}$

Struik PC, Ewing EE (1995) Crop physiology of potato (Solanum tuberosum): responses to photoperiod and temperature relevant to crop modelling. In: Haverkort AJ, MacKerron DKL (eds) Potato ecology and modelling of crops under conditions limiting growth, current issues in production ecology, vol 3. Springer, Netherlands, pp 19-40

Tibbitts TW, Bennett SM, Morrow RC, Bula RJ (1989) Utilization of white potatoes in CELSS. Adv Space Res 9:53-59

von Braun J (2007) The world food situation: new driving forces and required actions. Food policy report. IFPRI, Washington, DC

Wolf S, Marani A, Rudich J (1991) Effect of temperature on carbohydrate metabolism in potato plants. J Exp Bot 42:619-625 